\title{
Impact Of Village Financial Implementation On Village Financial Management Accountability
}

\author{
Indrian Supheni, Rahmawati, and Agung Nur Probohudono \\ Faculty Of Economics And Business Universitas Sebelas Maret Surakarta Indonesia \\ rahmaw2005@yahoo.com
}

\begin{abstract}
Accountability in the implementation and management of village finance is very important. Requires the village government to manage village finance professionally, effectively and efficiently, and responsibly. One source of village income that functions as a source of village operational activities and for community empowerment is the Village Fund. With the receipt of this fund, the village government must be prepared and able to manage village finance based on the principles of transparency, accountability, and participation in accordance with Minister of Home Affairs Regulation No. 113 of 2014. The purpose of this study is to determine the effect of village finance on village financial management accountability. The subject of this study was the village government in East Java. The sample in this study were 374 villages. The results show that the implementation of income receipts, expenditure implementation, and financing implementation have a significant influence on the accountability of village financial management.
\end{abstract}

Keywords: revenue implementation, expenditure implementation, financing implementation, accountability

\section{INTRODUCTION}

Village governments in exercising the authority of village financial management are nothing but to increase development towards a just, prosperous, and prosperous society. This can be traced from the legal text of (Law No. 6 of, 2014). According to Law No. 6 of 2014 states villages are traditional villages and villages or what are called by other names, hereinafter referred to as villages, are legal community units that have territorial boundaries authorized to regulate and manage government affairs, interests of the local community based on community initiatives, origin rights, and / or traditional rights that are recognized and respected in the system of government of the Unitary State of the Republic of Indonesia.

According to Article 71 Paragraph (6) of Law No. 6 of 2014, Village Finance is all Village rights and obligations that can be valued with money and everything in the form of money and goods related to the implementation of the rights and obligations of the Village. One village income source that can function as a source of village operational activities and for community empowerment is the Village Fund. The use of village funds refers to the RPJMDesa and RKPDesa. With the receipt of funds for the village, the village government must be prepared and able to manage village finance based on 
transparent, accountable, participatory principles and carried out in an orderly and disciplined manner in accordance with Minister of Home Affairs No. 113 of 2014 concerning guidelines for village financial management. Village Finance is managed through planning, budgeting, implementation, supervision, reporting, and village financial accountability carried out by the Village Head assisted by the Village Financial Management Technical Officer (PTPKD).

Accountability The implementation of village finance is part of village financial management and is also a stage that must be carried out by the village government. In Article 7 of Law No. 28 of 1999, Accountability is the principle that determines that every activity and outcome of the activities of the State must be accountable to the community or the people as the highest holder of the State in accordance with the applicable laws and regulations.

The reality that occurs related to village financial management shows that in the implementation of managing village finance there are various problems, namely in carrying out activities or programs that are not self-managed by the community, but using third parties or contractors. The principle of self-managed implementation does not mean that the Village Government and its resources carry out independently in carrying out activities. But the self-management in question is the Village Government forming a Village Implementation Team (TPK) that involves community social groups and is determined through a Decree of the Village Head.

In implementing village finance, there are a number of general principles that must be adhered to, including revenues and expenditures. The principle includes that all village revenues and expenditures are carried out through the Village Cash Account. The financial disbursement in the Village Cash Account is signed by the Village Head and the Village Treasurer. The implementation of the Financing includes the Receipt of Financing and Financing Expenditures.

Problems related to the low accountability of income receipts, namely in the village transfer section, there are problems related to revenue sharing of tax and retribution in the regency / city whose initial formulation of the government does not include the specific percentage of revenue sharing from regional taxes and levies which are the village's rights (village head). id). The low accountability about expenditure / expenditure is an indication of budget waste in the use of the APB Desa, so that activities that are built to provide benefits to the community cannot be maximized and the hope of being able to improve the community economy has not been achieved. The low level of accountability regarding financing is the difference between village income and expenditure which results in a surplus / income (BPKP, 2015). Problems that occur with Accountability are low welfare standards that can trigger employees to make deviations, to fulfill their needs by violating the principle of Accountability, character factors such as the habit of prioritizing family interests and relatives compared to service to the community and weak legal systems in finance and administration (academiaedu. com).

This research is important because Accountability means the responsibility of the village government in managing village finance in accordance with the "trust" and the trust given to it. Responsibility means managing finances well, honestly, not committing fraud. This research is limited to four variables used, namely the implementation of 
revenue, implementation of expenditure, implementation of financing and accountability. In this study discussing Accountability, whose scope is in the Village Government in East Java. Accountability referred to is Accountability for the Implementation of Village Financial Management which is a stage that must be implemented by the Village Government.

\section{THEORETICAL REVIEW}

Some of the previous studies that raised the issue of accountability in village government include (Grestly et al., 2016) who stated that the implementation of village funds in principle has been based on regulations, and implementation has not fully supported the principles principle of village financial management. (Nurul and Iin, 2017) examined the accountability of village fund management in Wonodadi Village, Ngrayun Subdistrict, Ponorogo Regency, resulting in the implementation of financial management of village funds not yet fully applying Accountability to the Transparency Principle because the village government was not yet open to people who needed village financial data. (Hasniati, 2016) in her research stated that the management of village funds starting from planning, implementation, and reporting has met the principle of Accountability.

Villages. According to Law No. 6 of 2014 state that villages are traditional villages and villages or what are called by other names, hereinafter referred to as villages, are legal community units that have territorial limits that are authorized to regulate and manage government affairs, interests of the local community based on initiatives community, origin, and or traditional rights that are recognized and respected in the system of government of the Unitary State of the Republic of Indonesia.

Village according to HAW Widjaja in his book entitled "Village Autonomy is genuine, round and intact autonomy" states that "Village is a legal community unit that has an original structure based on special origin rights".

In accordance with Law Number 6 of 2014 concerning village Article 25 that the Village Government is the Village Head or referred to by another name and who is assisted by the village apparatus or what is called by another name. Furthermore, in Article 26 of Law Number 6 of 2014 it is stated that the Village Head is in charge of organizing Village Government, implementing Village Development, Village Community Development, and Empowering village communities.

Village Finance. According to Law No. 6 of 2014 Article 71 paragraph (1) Village Finance is all Village rights and obligations that can be valued with money and everything in the form of money and goods related to the implementation of the rights and obligations of the Village.

According to Article 72 paragraph (1) of Law No. 6 of 2014 concerning Villages, Village Income is income derived from: (1) Village original income consisting of business income, asset yield, self-help and participation, mutual cooperation and other original income of theVillage. (2) Allocation State Budget Revenues and Expenditures. (3) from the results of regional taxes and retributions of Regency / City area. (4) Alocation of 
Village funds which are part of the balance funds received by Regency / City. (5) Financial Assistance from the Provincial Regional Revenue and Expenditure Budget and Regency / City Regional Revenue and Expenditure Budget. (6) grants and non-binding donations from third parties and. (7) other legitimate village income

According to Article 74 paragraph (1) of Law Number 6 Year 2014 concerning Villages, Village Expenditures are prioritized to meet agreed development needs in the Village Conference and in accordance with the priorities of the District Government / City, Provincial Government, and Government. According to Article 73 paragraph (1) of Law No. 6 of 2014 concerning Villages, the Village Revenue and Expenditure Budget consists of the share of income, expenditure and village financing. Furthermore, in paragraph (2) the draft Village Revenue and Expenditure Budget is submitted by the Village Head and discussed with the Village Consultative Body. In accordance with the results of the deliberations as referred to in paragraph (2), the Village Head determines the Village Revenue and Expenditure Budget each year with a Village Regulation. According to Article 1 paragraph (11) of Law Number 6 Year 2014 concerning Villages, Village Assets are Village property originating from the Village's original wealth, purchased or obtained at the expense of the Village Budget and other legal rights. According to Article 76 paragraph (1) Village assets can be in the form of village treasury land, ulayat land, village market, animal market, boat moorings, village buildings, fish auctions, auction of agricultural products, village-owned forests, village springs, public baths, and other assets belonging to the Village.

Village Financial Management. According to Permendagri No.113 of 2014 Village Financial Management is the entire activity which includes planning, implementation, administration, reporting, and accountability of village finance.

The implementation of village finances based on village origin and local-scale authority is funded by the APB Desa. The implementation of local scale village authority besides being funded by the APB Desa, can also be funded by the State Revenue and Expenditure Budget and the Regional Revenue and Expenditure Budget. The implementation of Village authority assigned by the Government is funded by the State Revenue and Expenditure Budget. Funds for the State Revenue and Expenditure Budget are allocated to the Ministry / Institution Budget section and are channeled through the district / city regional work units. The implementation of Village authority assigned by the regional government is funded by the Regional Revenue and Expenditure Budget. All village income is received and channeled through the village cash account and its use is determined in the APB Desa. Disbursement of funds in the Village cash account is signed by the Village Head. The Village Head is the holder of the Village's financial management power. In carrying out the power of village financial management, the Village Head authorized some of his power to the Village apparatus.

Village Fund. Village Funds according to Law No. 6 of 2014 are funds sourced from the State Revenue and Expenditure Budget (APBN) intended for villages that are transferred through the Regency / city Regional Revenue and Expenditure Budget (APBD) and are 
used to finance government administration, implementation development, community development, and community empowerment. Furthermore, based on the Law on Villages, authority is given to regulate and manage its authority in accordance with village needs and priorities.

Accountability. Accountability is the ability to give answers to higher authorities for the actions of a person / group of people towards the wider community in an organization (Syahrudin Rasul, 2002). Whereas According to (Jones, 1992), Accountability is associated with calling an individual to 'take responsibility' for their actions to a higher authority, with an emphasis on external supervision and the threat of potential sanctions. Level of Accountability according to Indonesian Accountants Magazine: (1) Personal Accountability, Accountability is related to oneself. (2) Individual Accountability, namely Accountability related to an implementation. (3) Team Accountability is Accountability which is divided into group or team work. (4) Organizational Accountability is internal and external Accountability within the organization. (5) Accountability of stakeholders is accountability that is separate between stakeholders and the organization.

According to (Syahrudin Rasul, 2002) in his book "Integration of Performance and Budget Accountability Systems in the Perspective of Law NO.17/2003 on State Finance" The Accountability Dimension has five elements, namely: (1) Legal accountability and honesty (Accountability for probity and legality). Legal accountability related to compliance with other laws and regulations required in the organization, while honesty accountability is related to avoidance of office abuse, corruption, and collusion. Legal accountability guarantees the supremacy of the law, while honesty accountability guarantees the existence of sound organizational practices. (2) Managerial Accountability. Managerial accountability that can also be interpreted as performance accountability is accountability for managing the organization effectively and efficiently. (3) Accountability program. Accountability program also means that organizational programs should be the achievement of the organization's vision, mission and goals. Public institutions must account for programs that have been made up to the implementation of the program. (4) Policy accountability. Public institutions should be able to account for the policies that have been determined by considering future impacts. In making a policy, it must be considered what the policy objectives are, why the policy is carried out. (5) Financial Accountability. This accountability is the responsibility of public institutions to usepublic moneyeconomically, efficiently and effectively, there is no waste and leakage of funds, and corruption. This financial accountability is very important because it is the main focus of the community. This accountability requires public institutions to make the organization financial to external parties.

According to (Guillermo O'Donnell, 1998), Accountability has two dimensions namely horizontal and vertical. (1) The horizontal dimension is mostly related to the effective operation of the inspection system and with legal processes in government decision making. (2) The vertical dimension focuses on elections and other mechanisms used by citizens to control their government. 
Accountability Aspects. There are several Aspects of Accountability (Academiaedu.com). (1) Accountability is a relationship. Accountability is two-way communication as explained by the Auditor General of British Columbia, which is a contract between two parties. (2) Result Oriented Accountability. In the organizational structure of the private sector and the public at present accountability does not look at the input or output but rather the outcome. (3) Accountability requires reporting. Reporting is the backbone of accountability. (4) Accountability is meaningless without consequences. The keywords used in discussing and defining accountability are responsibilities. That responsibility indicates obligations and obligations to come along with the consequences. (5) Accountability improves performance. The purpose of accountability is to improve performance, not to find fault and give punishment.

Types of Accountability. According to (Ulum, 2004) in his book "Public Sector Accounting" states that accountability can be divided into several types, including can be categorized into two parts, namely:

1) Internal Accountability. Applies to every level in the internal organization of the state including the government, where every public official / officer both individual / group is obliged to account to the supervisor regarding the development of the performance / results of the implementation of their activities periodically or at any time if deemed necessary. The requirement for internal government accountability, has been mandated in the Presidential instruction Number 7 of 1999 concerning the accountability of performance of government agencies. 2) External Accountability Adheres to each state institution as an organization to account for all orders that have been received and implemented or developments to be communicated to external parties and their environment.

Accountability indicators according to (Lolina Lalono Krina, 2003) namely. 1)The process of making a decision made in writing is available to citizens in need, with each decision taken fulfilling the ethical standards and values that apply, and in accordance with the correct administrative principles. 2) Accuracy and completeness of information relating to ways to achieve the objectives of a program. 3) Clarity of policy objectives that have been taken and communicated. 4) Dissemination of information about a decision through mass media public access to information on a decision after a decision is made and a public complaints mechanism. 5) Management information system and results monitoring.

The Importance of Accountability. According to (Aucoin and Heintzman, 2000), Accountability is very important, namely to show democratically how the government monitors and controls and prevents the concentration of power and increases the capacity and effectiveness of public administration learning. (Salminen and Ikola-Norrbacka, 2010) state that every government basically tries to appear good and reliable to the public. Anticorruption laws and codes of ethics have been established and enforced to avoid unethical actions against regulations. According to (Bovens, 2007), the concept of Accountability has developed and expanded into an integrated concept of financial management and 
stewardship of financial use. According to (Barton, 2006), public sector accountability requires the government to justify the sources and uses of public resources because most governments are considered inefficient and underperforming in service delivery.

Implementation of the APB Village. Implementation Village according to the (BPKP, 2015) in the book "Guidance for Implementation of Guidance \& Consultation on Village Financial Management."

Principles for Implementation of Village Finance. In implementing village finance, there are a number of general principles that must be adhered to, including revenues and expenditures. The principle includes that all village revenues and expenditures are carried out through the Village Cash Account. Disbursement of funds in the Village Cash Account is signed by the Village Head and the Village Treasurer. In its implementation, the Village Treasurer can save money in the village treasury in a certain amount to meet the operational needs of the village government. The limit on the amount of cash deposited in the village treasury is determined by the regent / mayor's regulations. In addition, in order for the operations of the activities to run smoothly, it is also possible for payments to third parties to be carried out by using cash cash through the executor of the activity (down payment). Provision of down-payment to the executor of the activity is carried out with prior approval from the village head after going through verification of the Village Secretary. All village revenues and expenditures are supported by complete and legal evidence and signed by the Village Head and Treasurer Village (BPKP: 2015).

Implementation of Revenue. Implementation of income receipts is the process of receiving and recording village income. Village income that is Village Original Income comes from the community and village environment, while the transfer income comes from the supra village government. The parties involved in the process of receiving income are funders (Central / Prov / District / City, Community, Third Parties), Fund Recipients (Village Treasurers / Actors / Hamlets) and banks (BPKP: 2015).

Village Original Income Village Original Income. Group includes Business Results, Asset Results, Self-Help, Participation and Mutual Assistance, and Others Original Village Income. All income received by the Village Treasurer must be deposited into the Village Cash Account.

Others Village Original Revenues, among others, are obtained from the results of village levies. Existing levies in the village include levies on the use of village halls, levies on making certificates, levies on prospective villagers, and so forth. Village governments are prohibited from leviing as village receipts other than those stipulated in village regulations (BPKP: 2015).

Village Transfer Village Transfer. Income as described above comes from the supra village government who channel funds to the village according to the mandate of the applicable provisions or financial assistance to the village. The Transfer Funds that will be given to the village have been stated in the relevant Provincial / District / City APBD 
which the village has previously informed, namely 10 days after the KUA / PPAS was agreed by the regional head and DPRD (BPKP: 2015).

Other. Income Other Income Groups -Other includes Grants, Donations from Nonbinding Third Parties and Others Legitimate Village Revenues. Implementation of receipts from Grants, Donations, and Others Legitimate Village Revenues, in the form of, are CASH carried out through the Village Treasurer. Income received in cash cash by the Village Treasurer must be immediately deposited into the Village Cash Account. Recording of receipts from Grants, Donations, and Others Legitimate Village Revenues must be accompanied by complete and valid evidence including receipts of receipt (BPKP: 2015).

The implementation of Village Expenditures. Expenditures is prioritized to meet the development needs agreed upon in the Village Conference and in accordance with Government priorities both the central government and the provincial / district / city government. All of this is contained in the Village RKP which will be implemented through the APB Desa. After the Village APB is established in the form of a Village Regulation, programs and activities as planned have only been implemented. This is excluded for Employee Expenditures that are binding and office operations which are regulated in the Decree of the Village Head. With the provisions of the village head, employee and operational expenditure can be carried out without the need to wait for the establishment of the APB Desa (BPKP: 2015).

The Financing and Expenditure for Financing. Receipts for Financing includes SiLPA in the previous year, Disbursement of Reserve Funds and proceeds from Separated Village Wealth Sales. Remaining Over Budget Calculation is financing receipts used to fund the implementation of current year activities derived from exceeding revenue receipts and expenditure savings in the previous year. The realization of the use of SiLPA is the entire SiLPA budgeted in the APB Village. Disbursement of the Reserve Fund is an activity of disbursing funds from a reserve fund account to a village account that is carried out according to the Village Regulations that regulate this matter. Whereas financing receipts originating from Separated Village Wealth Sales results are obtained from the realization of the sale of assets / wealth of the village to third parties. Strategic sales of village property must be done through village meetings first, which are then stipulated in village regulations or decisions of the village head that refer to the provisions of the management of Village Property. Village Property can be sold only if it has no benefits in supporting the administration of the village government and / or is approved in village meetings (BPKP: 2015).

Expenditures include the Establishment of a Reserve Fund and Participation in Village Capital. The establishment of a Reserve Fund is carried out after the establishment of an agreement through a Village Regulation. The establishment of a Reserve Fund is placed in a separate account and the budget does not exceed the final year of office of the Village Chief. Likewise, the case for Village Capital Participation is carried out after obtaining approval from the Village Consultative Body (BPKP: 2015). 
The relationship between variables. Demands for the implementation of revenue, expenditure, and financing is an obligation that must be carried out by the Village Government, which then must be accounted for. The better the implementation of revenue, expenditure, and financing receipts the better the level of accountability of village financial management. More complete can be seen in Figure 1 below.

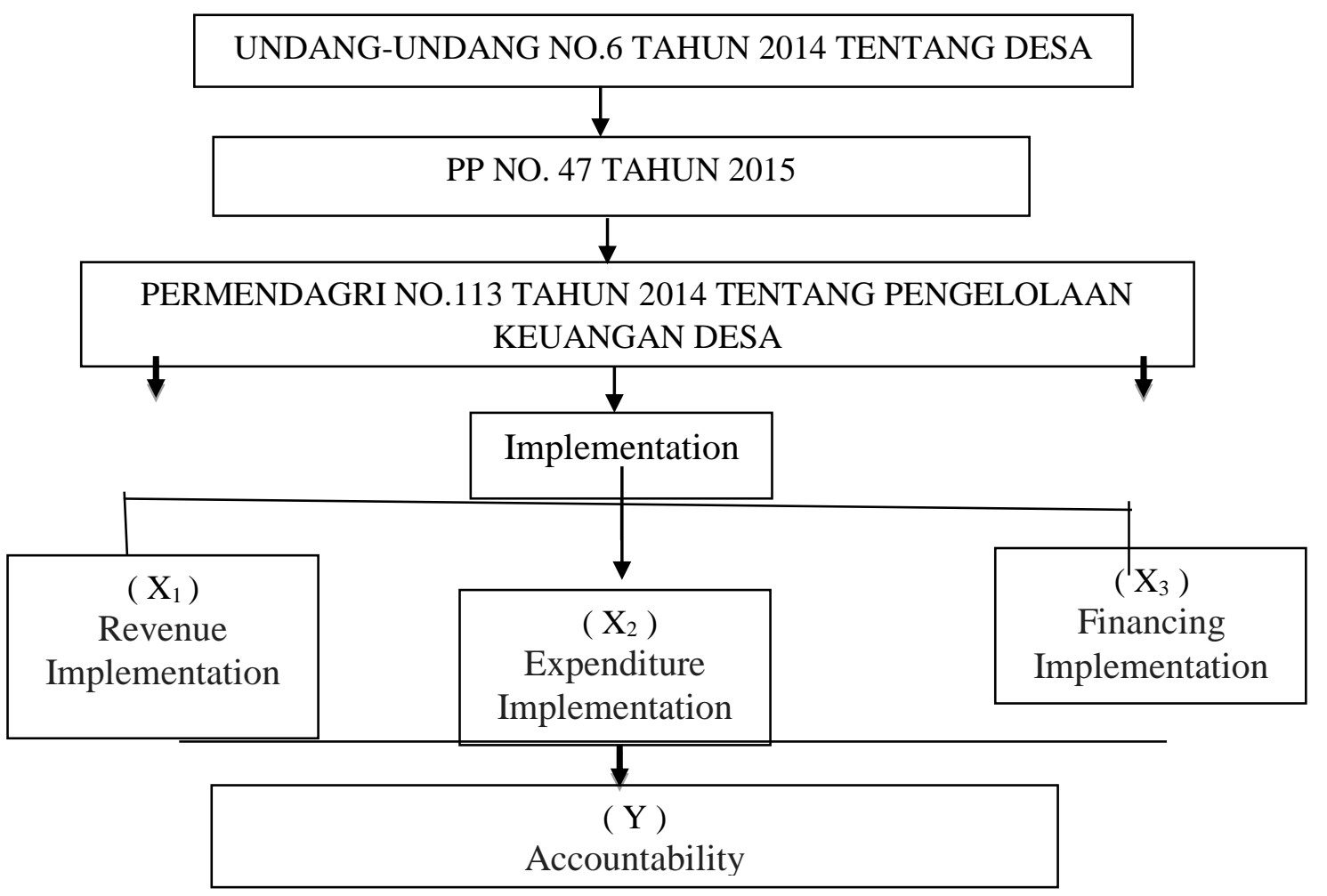

Figure 1. Relationship between variables

The purpose of this study is to prove the effect of the implementation of income receipts on the accountability of village financial management. Implementation Revenue receipts are all receipts of money through village cash accounts that are village rights in 1 fiscal year that do not need to be repaid and any income received in the form of cash or non-cash / transfers must be accompanied by complete and legal evidence, and properly recorded and orderly (BPKP: 2015). According to Permendagri Number 113 of 2014 Accountable is defined as the realization of the obligation to account for the management and control of resources and the implementation of the policies entrusted in order to achieve the stated objectives. Therefore, so that the performance of the village government can be accounted for, it is necessary to manage the implementation of income receipts properly.

$\mathbf{H}_{1}$ : Implementation of Revenue has an effect on Accountability of village financial management.

The expenditure is all expenditure from the village account which is the obligation of the village in 1 budget year that will not be repaid by the village and in each expenditure there are ways for the Village Treasurer to make payments, namely the 
Village Treasurer makes payments without going down and the Village Treasurer does advance payment in advance to the executor of the activity. Accountability is defined as accountability (Wikipedia). This study aims to determine the effect of the implementation of expenditure on the accountability of village financial management. Therefore, so that government performance can be accounted for, it is necessary to manage the implementation of expenditure properly.

$\mathbf{H}_{2}$ : Expenditures implementation affects the accountability of village financial management.

In this study it is assumed that the suitability of the Village Financial Financing Implementation with the applicable Regulations and Regulations will affect the Accountability of Village Financial Management, because according to the BPKP (2015) in the book "Guidance for Implementation of Guidance \& Consultation on Village Financial Management" every establishment of fund reserves and disbursement reserves must be in accordance with Village Regulations. Therefore, so that the performance of the village government can be accounted for, then it must manage the implementation of financing according to village regulations properly.

$\mathbf{H}_{3}$ : Financing Implementation affects the accountability of village financial management.

In this study, it is assumed that the suitability of the Village Income, Expenditures and Financial Financing Receipts with the applicable Regulations and Regulations will affect the Accountability of Village Financial Management, because according to the BPKP (2015) in the book "Guidance for Implementation of Guidance \& Village Financial Management Consultation" as a whole Implementation of activities must be carried out in accordance with the Village Regulations. In order for the performance of the village government to be accounted for, the overall implementation of income receipts, implementation of expenditures, and implementation of financing must be managed properly and in accordance with village regulations.

$\mathbf{H}_{4}$ : Revenue from Income, Expenditures, and Financing affects the accountability of village financial management.

\section{METHODOLOGY}

This study adheres to the quantitative paradigm and based on its level of exploration is still included in the type of descriptive research. The unit of analysis in this study is the area of East Java whose data is taken from Villages in the East Java area. This research was carried out in the villages in the East Java area. In this study the population is all villages in the East Java area, with 5674 villages. The form of sampling in this study is probability sampling using Proportionale Random Sampling. Determine the number of samples from a population using the Slovin formula with an Uncertainty Tolerance of 5\% obtained by a sample of 374 villages. 
Table 1. Data of Respondents

\begin{tabular}{c|l}
\hline Nu & \multicolumn{1}{|c}{ Positition } \\
\hline 1 & Village Head (Kepala Desa) \\
\hline 2 & Treasurer (Bendahara) \\
\hline 3 & Other \\
\hline
\end{tabular}

This study consists of two types of variables which include:

(1) Independent Variables (Independent) Independent. variables are variables that influence or become the cause of changes or the emergence of dependent or dependent variables (Sugiyono, 2011). The independent variable in this study is the implementation of income receipts that can be measured through four indicators, the implementation of expenditures that can be measured through six indicators, and the implementation of financing that can be measured through three indicators. (2) Bound Variables (Dependent). Bound variables are variables that are affected or become a result, because there are independent variables (Sugiyono, 2011). The dependent variable in this study is the accountability of village financial management which can be measured through three indicators.

The description of this research variable was conducted to examine the responses of respondents who were used to see the tendency of respondents to assess the implementation of income receipts, implementation of expenditures and implementation of financing on accountability of village financial management through questionnaires.

The data collection technique used in this study was using a questionnaire or questionnaire. The instruments used in this study were questionnaires or questionnaires. The instrument used in the study is intended to produce accurate data using a Likert Scale, with a rating scale of 1 to 5. The analysis used is the Linear Regression analysis which aims to determine the effect of independent / independent variables on the dependent variable. This study consists of more than one independent variable, then the regression used is multiple linear regression.

\section{EMPIRICAL RESULTS}

Test Validity and Reliability. Based on calculations through SmartPLS, it can be concluded that all instruments used for research Implementation of Revenue, Execution of Expenditures, and Financing Implementation is valid, because it is evident that the coefficient value is greater than the value of criticism or table at a significant level of $5 \%$. It means that all instruments for the implementation of income receipts, expenditure implementation, and financing implementation can be used appropriately to measure village financial management accountability.

Based on the calculation through SmartPLS, we can say that all variables used in this study is reliable, this is because the coefficient Cronbach's Alphais above 0.6. Based on the results of the analysis it can be said that all instruments are in the penel this matter even though repeated testing can produce the same results so that it can be used to explain the effect of the implementation of income receipts, expenditure implementation, and the 
implementation of financing of village financial management accountability in the Village Government in East Java.

Table 2. Validity and Reliability Test Results on Pilot Test

\begin{tabular}{lccc}
\hline Variable & Loading & $\begin{array}{c}\text { Composite } \\
\text { Reliability }\end{array}$ & AVE \\
\hline Revenue & 0,894 & 0,828 & 0,575 \\
Implementation & 0,892 & & \\
RI1 & 0,787 & & \\
RI2 & 0,289 & & 0,520 \\
RI3 & & & \\
RI4 & & & \\
\hline Expenditure & 0,510 & & \\
Implementation & 0,531 & & \\
EI1 & 0,328 & & \\
EI2 & 0,891 & & \\
EI3 & 0,911 & & \\
EI4 & 0,921 & & \\
EI5 & & & \\
EI6 & & & \\
\hline Financing & 0,549 & & \\
Implementation & 0,793 & & \\
FI1 & 0,813 & & \\
FI2 & & & \\
FI3 & & & \\
\hline Accountability & 0,850 & & \\
A1 & 0,923 & & \\
A2 & 0,857 & & \\
A3 & $2018)$ & & \\
\hline
\end{tabular}

Source: (primary data processed, 2018)

The output of Cross Loadings requires that the correlation value of each indicator with its latent variables be greater, when compared with the correlation between each indicator of Revenue Implementation with the Expenditure implementation, Financing implementation and accountability. Analysis has proven.

Analysis. Based on the analysis results can it was concluded that each independent variable had a positive effect on the dependent variable. From the results of the calculation of multiple linear regression analysis that has been done shows the ability of the model in explaining the effect of independent variables on the variable dependent is large, it can be seen in the value of Adj. R. Square which is equal. Thus it means that the regression model used is able to explain the effect of village finance implementation variables which 
consist of income receipts, expenditure implementation, financing implementation of village financial management accountability.

Table 3. Model Fit dan Quality Indices

\begin{tabular}{lccc}
\hline \multicolumn{1}{c}{ Item Model Fit } & Nilai & Criteria & Conclusion \\
\hline Average path coeffient (APC) & $0,196, \mathrm{P}<0,001$ & $\mathrm{P}<0,05$ & Corresponding \\
Average - squared (ARS) & $0,201, \mathrm{P}<0,001$ & $\mathrm{P}<0,05$ & Corresponding \\
Average block VIF (AVIF) & 1,339 & $\mathrm{AVIF}<5$ & Corresponding \\
\hline
\end{tabular}

Source: primary data processed (2018)

From the description of the results of $t$ count and table can be described the results of the analysis partially which can be described as follows: (1) Variable revenue implementation has a partial effect on accountability of village financial management, from the results of partial calculations show that corresponding. It can be said that partially the income receipt variable significantly influences the accountability of village financial management. (2) The expenditure implementation variable has a partial effect on the accountability of village financial management, from the results of partial calculations shows that corresponding confidence level. By testing statistics. It is said that partially the variable implementation of expenditure has a significant effect on the accountability of village financial management. (3) The variable implementation of financing has a partial effect on accountability Village financial management shows that corresponding. With statistical tests obtained it is said that in partial implementation of the funding of a significant effect on the accountability of the financial management of the village.

Hypothesis Testing

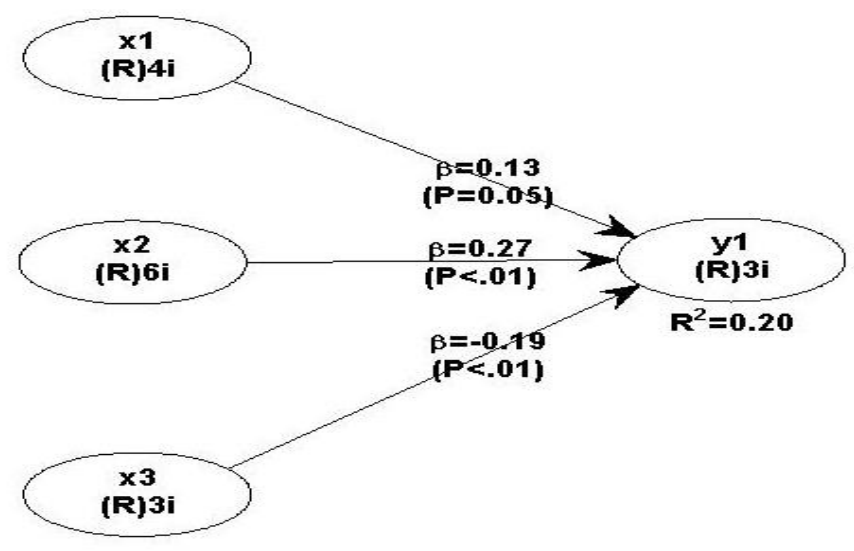

Source: Primary data processed (2018)

\section{DISCUSSION}

The Effect Of Implementing Income Receipts Partially On Accountability In Village Financial Management. Based on the results of the research and discussion that have 
been conducted, the results of the analysis can be seen that there is a significant effect between the implementation of income receipts on accountability of village financial management in the Village Government in East Java. The existence of a significant influence shows that with the better implementation of revenue receipts, the accountability of village financial management in the Village Government in East Java will increase. This condition shows that with the better implementation of income receipts in this case regarding receipt of income received must be accompanied by complete and legal evidence, it can increase the accountability of village financial management. This research is also supported by the theory put forward by (BPKP: 2015) in the book "Implementation Guidance \& Village Financial Management Consultation" which states that any income in the form of cash or non-cash / transfer must be accompanied by complete and legal evidence, and recorded correctly and orderly.

Effect of partial expenditure implementation on Accountability in village financial management. Based on the results of the research and discussion that have been conducted, the results of the analysis can be seen that there is a significant influence between the implementation of expenditure on the accountability of village financial management in the Village Government in East Java. The existence of a significant influence shows that with the better implementation of expenditure, the accountability of village financial management in the Village Government in East Java will increase. These conditions indicate that with the better implementation of expenditure in this case regarding the stages of the treasurer making payments, it can increase the accountability of village financial management. This research is also supported by the theory put forward by (BPKP: 2015) in the book "Guidance for Implementation of Guidance \& Consultation on Village Financial Management" which states that at each expenditure there are ways for the Village Treasurer to make payments, namely the Village Treasurer makes payments without going down and the Village Treasurer prepares payments in advance to the executor of the activity.

The effect of partial financing implementation on village financial management accountability. Based on the results of the research and discussion that have been conducted, the results of the analysis can be seen that there is a significant influence between the implementation of the financing of the accountability of village financial management in the Village Government in East Java. The existence of a significant influence shows that with the better implementation of financing, the accountability of village financial management in the Village Government in East Java will increase. This condition shows that with the better implementation of financing in this case regarding the formation of a reserve fund, it can increase the accountability of village financial management. This research is also supported by the theory put forward by (BPKP: 2015) in the book "Implementation Guidelines for Guidance \& Consultation on Village Financial Management" which states that each establishment of reserve funds and disbursement of reserve funds must be in accordance with Village Regulations. 
Influence of Implementation of Revenue Acceptance, Execution of Expenditures, and Financing Implementation simultaneously on Accountability of village financial management. Based on the results of data analysis using multiple linear regression shows that there is a simultaneous influence between the implementation of income receipts, expenditure implementation, and implementation of financing for village financial management Accountability in the Government Village in East Java. These results indicate that with the change or increasing implementation of income receipts, implementation of expenditures, and the implementation of financing, the accountability of village financial management in the Village Government in East Java will also increase. Thus it can be said that the fourth hypothesis is accepted, which states that the implementation of income receipts, expenditure implementation, and the implementation of financing have an effect on simultaneously on the accountability of village financial management in the Village Government in East Java. This research is also supported by the theory put forward by (BPKP: 2015) in the book "Implementation Guidelines for Guidance \& Consultation on Village Financial Management" which states that overall the implementation of activities must be carried out in accordance with Village Regulations.

\section{CONCLUSION}

From the results of the research and discussion using multiple linear regression analysis that has been done, it can be concluded that the implementation of income receipts, expenditure implementation, and financing implementation significantly influence the accountability of village financial management. The F Test results indicate the implementation of revenue, expenditure, and the implementation of simultaneous financing also have a significant effect on the accountability of village financial management. This shows that in the village financial management the village apparatus has managed well the implementation starting from the receipt of income, the implementation of expenditure and implementation of financing so that it can improve the accountability of village financial management in the village government in East Java.

Limitations Of The Research

This research was only conducted in one of the regencies in Indonesia. To be able to capture the condition of management overall village funding Indonesia in subsequent studies, it can use more samples, namely several villages in other districts in Indonesia.

\section{REFERENCE}

Abidin, M.Z. (2015). Tinjauan Atas Pelaksanaan Keuangan Desa Dalam Mendukung Kebijakan Dana Desa. Jurnal Ekonomi \& Kebijakan Publik. Vol.6, No.1, hlm.61-76.

Barton, A.D. (2006). Public sector accountability and commercial-in confidence outsourcing contracts. Account. Audit. Accountabil. J. 19: 256-271.

Bintarto,R. (1984). Geografi Desa. Yogyakarta : Fakultas Geografi UGM.

Bovens, M. (2007). New forms of accountability and EU-governance. Comp. Eur. Politics. 5: $104-120$. 
Brown, J., Dillard, J., Hopper, T. (2015). Accounting, accountants and accountability regimes in pluralistic societies. Accounting, Auditing \& Accountability Journal 28, 626-650.

Burhanuddin, A. (2013). Analisis Validitas dan Reliabilitas Data. Diakses pada 21 Mei 2013, dari https://afidburhanuddin.wordpress.com/2013/05/21 /analisis-validitasdan-reliabilitas-data.

David, F., Abreu, Rute., Pinheiro, Odete. (2013). Local action groups: accountability, social responsibility and law. International Journal of Law and Management 55, 527.

Deputi Bidang Pengawasan Penyelenggaraan Keuangan Daerah. (2015). Petunjuk Pelaksanaan Bimbingan \& Konsultasi Pengelolaan Keuangan Desa : Jakarta.

Devaney, Laura. (2016). Good Goverment? Perceptions of accountability, transparency and effectiveness in Irish food risk governance. Food Policy 62, 1-10.

Elstad, E., Christophersen, K.A., Turno, A. (2012). The strenght of accountability and teachers' organisational citizenship behaviour. Journal of Educational Administration 50, 612-628.

Emeseh, E., Songi, O. (2014). CSR, human rights abuse and sustainability report accountability. International Journal of Law and Management 56, 136-151.

Ferry, L. Eckersley, P. Zakaria, Z. (2015). Accountability and Transparency in English Local Government: Moving from 'Matching Parts' to 'AwkwardCouple'. Journal of Financial Accountability \& Management.

Ghozali, I. (2006). Aplikasi Analisis Multivariate dengan Program SPSS (Edisi Ke 4). Semarang: Badan Penerbit Universitas Diponegoro.

Ghozali, I. (2011). Aplikasi Analisis Multivariate Dengan Program SPSS. Semarang: Badan Penerbit Universitas Diponegoro.

Gray, R., Bebbington, J., Collison, D. (2006). NGOs, civiland accountability: making the people accountable to capital. Accounting, Auditing \& Accountability Journal 19, 319-348.

Gray, A., and Jenkins, Bill. (1993). Codes of Accountability in the New Public Sector. Accounting, Auditing \& Accountability Journal 6.

Haidin, S. (2017). Pelaksanaan Pengelolaan Keuangan Desa Setelah Berlakunya UndangUndang Nomor 6 Tahun 2014 Tentang Desa. Jurnal IUS. Vol.V, No.1, hlm.144161.

Halim, Abdul. (2007). Akuntansi dan Pengendalian Pengelolaan Keuangan Daerah. Yogyakarta: UPP STIM YKPN.

Haraldsson, Mattias. (2016). Transparency and accountability lost? Full cost accounting reporting in the Swedish municipal solid waste business. Journal of Accounting \& Organizational Change 12.

Harrison, Teresa M., Sayogo Djoko Sigit. (2014). Transparency, participation, and accountability practices ini open goverment: A comparative study. Goverment Information Quarterly 31, 513-525.

Hasniati. (2016). Model Akuntabilitas Pengelolaan Dana Desa. Jurnal Analisis dan pelayanan publik. Vol.2, No.1, Juni 2016. 
Hemmer, L.M., Madsen, J., Torres, M.S. (2013). Critical analysis of accountability policy in alternative schools: implications for school leaders. 51, 655-679.

Hidayah, N. and Wijayanti, I. (2017). Akuntabilitas Pengelolaan Dana Desa (DD). Jurnal AKSI (Akuntansi dan Sistem Informasi), Vol.1.

Ikatan Akuntan Indonesia-KSAP. 2015. Pedoman Asistensi Akuntansi Keuangan.

Jacobs, Kerry. (2000). Evaluating accountabilitty: finding a place for the Treaty of Waitangi in the New Zealend public sector. Accounting, Auditing \& Accountability Journal 13, 360-380.

KBBI. (2018). Kamus Besar Bahasa Indonesia (KBBI). Diaskes pada 05 April 2018, dari https://kbbi.kemdikbud.go.id.

Krina, L.L. (2003). Indikator Alat Ukur Prinsip Akuntabilitas, transparansi, dan partisipasi. Jakarta : Badan Perencanaan Pembangunan Nasional.

Mamelo, G.Y.R., Kalangi, L., Lambey, L. (2016) Analisis Pelaksanaan dan Penatausahaan Dana Desa pada Desa-Desa dalam wilayah Kecamatan Kotamobagu. Jurnal riset Akuntansi dan Auditing. Vol.7 No.2.

Manopo, Delviyanti Cristin. (2015). Pelaksanaan Akuntabilitas dalam Penyelengarakan Pemerintah Desa (Studi didesa Warisa, Kecamatan Talawan Kabupaten Minahasa Utara).

Mardiasmo, (2009). Akuntansi Sektor Publik. Edisi empat. Yogyakarta: Andi.

McPhail, K., Nyamori, R.O., Taylor, S. (2016). Escaping accountability: a case of Australia's asylum seeker policy. Accounting, Auditing \& Accountability Journal 29, 947-984.

Mayumana, Iddy., Borghi Jo., Anselmi, Laura., Mamdani Masuma., Lange Siri. (2017). Effects of Payment for Performance on accountability mechanisms: Evidence from Pwani, Tanzania. Social Sciene \& Medicine 179, 61-73.

Melawis. (2017). Banyak Permasalahan Terkait Pengelolaan Dana Desa . diakses pada tanggal 1 juni 2017, dari http://melawinews.com/2017/06/01/banyak-permasalahanterkait pengelolaan-dana-desa.online.

Mertkan, S., Sugrue, C. (2014). Building institutional capacitty: more accountability than autonomy?. Journal of Organizational Change Management 27, 331-343.

Mohammed, Munif. (2013). Corporate accountability in the context of sustainability - a conceptual framework. EuroMed Journal of Business 8, 243-254.

Mulyana, Budi. (2006). Pengaruh Penyajian Neraca Daerah dan Aksesibilitas Laporan Keuangan terhadap Transparansi dan Akuntabilitas Pengelolaan Keuangan Daerah. Jurnal Akuntansi Pemerintahan.

Mustofa, Anies Iqbal. (2012). Pengaruh Penyajian dan Aksesibilitas Laporan Keuangan terhadap Akuntabilitas Pengelolaan Keuangan Kabupaten Pemalang. Accounting Analysis Journal. ISSN 2252-6765. Universitas Negeri Semarang.

Nordberg, Donald. (2014). Viewpoint: governing the governance of the governors: Motivating accountability at the top of public organizations. Evidence-based HRM: a Global Forum for Empirical Scholarship 2, 114-119.

Nurunnabi, Mohammad., Islam, S.K. (2012). Accountability in the Bangladeshi privatized healthcare sector. International Journal of Health Care Quality Assurance 25, 625644. 
Utra, D. (2013). Pengaruh Akuntabilitas Publik dan Kejelasan Sasaran Anggaran Terhadap Kinerja Manajerial Satuan Kerja Perangkat Daerah. Jurnal Akuntansi. Vol.1, No.1.

Rahman, M., Hussain, M. (2012). Social business, accountability, and performance reporting. Humanomics 28, 118-132.

Ramon, Dolly. (2014). Pengaruh Sistem Pengendalian Internal terhadap Akuntabilitas Keuangan (Studi Empiris Pada Inspektorat Kota Se Provinsi Sumatera Barat). Jurnal Akuntansi Fakultas Ekonomi Universitas Bung Hatta.

Rasul, S. (2002). Pengintegrasian Sistem Akuntabilitas Kinerja dan Anggaran. Jakarta: Detail Rekod.

Republik Indonesia. (1999). Undang-Undang RI Nomor 28 Tahun 1999 Tentang Akuntabilitas.

Republik Indonesia. (2008). Peraturan Pemerintah No. 60 tentang Sistem Pengendalian Internal Pemerintah (SPIP).

Republik Indonesia. (2014). Undang-Undang RI Nomor 06 Tahun 2014 Tentang Desa.

Republik Indonesia. (2014). Peraturan Pemerintah RI Nomor 43 Tahun 2014 Tentang Peraturan Pelaksanaan Undang-Undang Nomor 06 Tahun 2014 Tentang Desa.

Republik Indonesia. (2014). Peraturan Pemerintah RI Nomor 60 Tahun 2014 Tentang Dana Desa Yang Bersumber Dari APBN.

Republik Indonesia. (2014). Peranturan Menteri Dalam Negeri Nomor 113 Tahun 2014 Tentang Pedoman Pengelolaan Keuangan Desa.

Republik Indonesia. (2015). Peraturan Menteri Dalam Negeri Nomor 83 Tahun 2015 Tentang Pengangkatan dan Pemberhentian Perangkat Desa.

Republik Indonesia. (2015). Peraturan Pemerintah RI Nomor 22 Tahun 2015 Tentang Perubahan Pengalokasian Dana Desa Yang Tercantum Dalam Pasal 11.

Riyansa, Ridho, Yunilma dan Fauziati Poppy. 2015. Pengaruh Penyajian Laporan Keuangan dan Aksesibilitas Laporan Keuangan Terhadap Akuntabilitas Pengelolaan Keuangan Daerah (Studi Empiris Pada Pemerintah Kabupaten Padang Pariaman). Jurnal Akuntansi Fakultas Ekonomi Universitas Bung Hatta.

Sabadoz, C., McShane, L. (2016). Organizational accountability relations: de facto or de jure?. Social Responsibility Journal 12, 32-53.

Suhardjanto, D, (2016), Telaah Kearifan Lokal Terhadap Akuntabilitas Lumbung Desa, Jurnal Ekonomi dan Bisnis, Vol 19, No 1 .

Said, J. Alam, M. and Azizal, M. (2015). Public Accountability System: Empirical Assessment of Public Sector of Malaysia. Asian Journal of Scientific Research 8. Page 225-236.

Salminen, A. and R. Ikola-Norrbacka. (2010). Trust, good governance and unethical actions in Finnish public administration. Int. J. Public Sector Manage., 23: 647-668.

Santoso, S. (2002). SPSS Versi 11,5. Cetakan Kedua Jakarta : Gramedia.

Santoso, S. (2012). Statistik Parametik. Jakarta : PT Gramedia Pustaka Umum.

Sekaran, U. (2006). Research Methods For Business (Metode Penelitian untuk Bisnis), Edisi empat buku 1. Jakarta : Salemba Empat.

Sekaran, U. (2011). Research Methods for business Edisi I and 2. Jakarta: Salemba Empat. 
Simperdede Demak. (2018). Anggaran Dana Desa . diaskes pada 16 Januari 2018, dari https://simperdededemak.wordpress.com/anggaran-dd-2.

Sugiyono. (2003). Metode Penelitian Bisnis. Edisi 1. Bandung : Alfabeta.

Sugiyono. (2014). Metode Penelitian Kuantitatif Kualitatif dan R\&D . Bandung : Alfabeta.

Sukmadinata. (2006). Metode Penelitian Pendidikan. Bandung : Remaja Rosdakarya.

Ulum, I. (2004). Akuntansi Sektor Publik: Suatu Pengantar. Jakarta : Bumi Aksara.

Widjaja, H.A.W. (2003). Otonomi Desa Merupakan Otonomi Yang Asli, Bulat, dan Utuh. Jakarta: RajaGrafindo Persada.

Wood, J.A., and Winston, B.E. (2007). Development of three scales to measure leader accountability. Leadership \& Organization Development Journal 28, 167-185.

Yaacob, H., Petra, S., Sumardi, A., and Nahar, H.S. (2015). Accountability throughaccounting and reporting lenses: Lessons from an awqaf institution in a Southeast Asia country. Humanomics 31, 299-313.

Yuliansyah \& Rusmianto. (2015). Akuntansi Desa. Jakarta : Salemba Empat. 